\title{
TEMPO E CIÊNCIA
}

\author{
Time and science $\mid$ Tiempo y ciencia
}

Silvânia Siebert*

Universidade do Sul de Santa Catarina, Programa de Pós-Graduação em Ciências da Linguagem, Tubarão, SC, Brasil

No ano de 2020 a pandemia provocada pelo vírus Sars-Cov2, denominada Covid19, constitui-se como um acontecimento histórico mundial. Um vírus com alto poder de contágio alterou o modo de viver, compreender e significar o mundo. A palavra lockdown ou confinamento determina(va) nossos dias, semanas e meses a partir do alvorecer deste ano. $\mathrm{O}$ contexto foi narrado, em diferentes idiomas, todos os dias, em forma de placares, pelos telejornais apresentando os números dos contágios, das mortes, entre outros dados.

A rotina planetária passou para o uso frequente de máscaras, ampliação de medidas de higiene e de segurança social, restrições nos transportes de carga e passageiros em rotas nacionais e internacionais, adoção do distanciamento social, inclusive entre familiares, alteraram de forma única o viver neste planeta. Entre tantas emoções deflagradas pelo fenômeno, sentimos o medo da perda, da finitude. Sentimos medo do tempo. O calendário sofreu ajustes impensáveis. O tempo passou a ser mostrado para além das previsões metereológicas. Começou a figurar em manchetes de jornais, anúncios publicitários, memes, nas conversas do dia a dia, na realização de trabalhos, de tarefas do cotidiano. Adentrou o pensar, as reflexões dos sujeitos, tornou a compreensão da existência humana assunto central e determinante.

Nas diferentes dimensões temporais, o tempo histórico passou a pressionar o tempo da ciência. Há necessidade de ser encontrada uma solução o quanto antes. Uma cura. Diante da ameaça, pesquisadores, em especial os ligados à área da saúde, de todos os continentes, passaram a investigar e a buscar um tratamento, entre eles um dos mais promissores, o desenvolvimento de vacinas. Mas, o tempo histórico e o da ciência avançam e nada de confirmações ou certezas.

Neste editorial buscamos pensar sobre esta relação entre o tempo histórico e o tempo da ciência. Para pensar o ano de 2020 em sua narrativa sobre a pandemia, a partir de uma perpectiva fundamentada nas ciências da linguagem, recorremos a Bakhtin (2018), em especial ao conceito de cronotopo, a relação entre tempo e espaço envolvendo autor e leitor. Desse encontro vemos que há a heterotemporalidade, como Bakhtin nomeou a simultaneidade de tempos. Uma perspectiva que privilegia o múltiplo e a simultaneidade.

\footnotetext{
* Doutora em Linguística Aplicada pela Universidade Estadual de Campinas. Docente do Programa de Pósgraduação em Ciências da Linguagem da Universidade do Sul de Santa Catarina. Editora de Linguagem em (Dis)curso. ORCID: https://orcid.org/0000-0002-7852-0968. E-mail: silvania@cinemaistv.com.br.
} 
Se, na produção artítica, temos o tempo do acaso, na ciência temos o tempo da certeza. Seria isso? Talvez até há bem pouco tempo poderíamos pensar assim. Diante do que vemos no transcorrer do tempo histórico-social são várias as versões de estudos, carregados de diferentes perspectivas teóricas. Irene Machado (1998), ao explicar o conceito de tempo na obra de Bakhtin, fala do tempo histórico, que "abarca os desígnios mais complexos dos homens, das gerações, das épocas, dos povos, dos grupos e classes sociais." (1998, p. 37). A pesquisadora ainda considera que Bakhtin entende a forma narrativa como modelo artístico do tempo. Neste ponto apareceram os gêneros discursivos como nucleadores.

Para ilustrar esta questão, mencionamos os artigos científicos que são publicados nesta edição. Os textos abordam temas como a violência familiar contra crianças e adolescentes; narcisismo discursivo debatido a partir de memes postados no Facebook; o "novo" Ensino Médio em propagandas; a discussão das contradições sociais nas obras No chão da fábrica, de Roniwalter Jatobá, e De mim já não se lembra, de Luiz Ruffato; a representação sobre autoridades policiais e jurídicas em anedotas publicadas no jornal católico Santuario da Trindade; a política de línguas do governo Vargas e, por último, um artigo que estuda como orelhas e capas de livros funcionam como espaços enunciativos para a promoção de obras literárias. Temos uma plêiade de temporalidades e pontos de vista diferentes envolvendo a pesquisa cientítica.

Em todos os trabalhos poderemos ver o funcionamento dos gêneros em múltiplas dimensões e espaços - tecendo narrativas sobre objetos que são delineados, analisados e interpretados pelas lentes da ciência. É importante observar que, de acordo com Machado (1998, p. 33), “o tempo na teoria do dialogismo não é um constituinte esturutral da narrativa, pelo contrário, a narrativa e, consequentemente, os gêneros são instâncias estéticas de representações do tempo". Múltiplas temporalidades operam em várias direções, e, conforme a autora, devemos perceber a narrativa como uma diversidade de quadros que retratam a complexidade humana.

Nas imagens de 2020 vemos um mundo afetado pela Covid-19, na dimensão do tempo histórico, datado e narrado com dados de infectados e de óbitos, operando o social por ferramentas tecnológicas que colocam em contato pessoas de forma remota. Um tempo que reivindica sensibilidade estética e ética e pesquisas em áreas como a das ciências da linguagem, que se coloca como o lugar privilegiado para a compreensão da narrativa como lugar para pensar o homem e o mundo - em um tempo em que o múltiplo, o diverso, seja uma alternativa possível para a pesquisa científica.

\section{REFERÊNCIAS}

Bakhtin, M. Teoria do romance II: as formas do tempo e do cronotopo. Tradução, posfácio e notas de Paulo Bezerra; organização da edição russa de Seguei Botcharov e Vadim Kójinov. São Paulo: Editora 34, 2018.

MACHADO, I. A. Narrativa e combinatória dos gêneros prosaicos: a textualização dialógica. Revista Itinerários, Araraquara, n.12, p. 33-46, 1998. 